ROCZNIKI TEOLOGICZNE

Tom LXVI, zeszyt 11 - 2019

DOI: http://dx.doi.org/10.18290/rt.2019.66.11-9

TERESA ZUBRZYCKA-MACIĄG

JUSTYNA RAK

\title{
KARA ŚMIERCI VERSUS PRAWO DO ŻYCIA W OPINII PRZYSZŁYCH PEDAGOGÓW
}

\author{
CAPITAL PUNISHMENT VERSUS THE RIGHT TO LIFE \\ IN THE OPINION OF FUTURE PEDAGOGUES
}

\begin{abstract}
A b s t r a c t. Person's attitudes, choices and the way in which he or she evaluates life events are determined by the system of values he or she adheres to. In the era of axiological chaos, the values that condition the perseverance of human existence and the continuity of the world order acquire particular significance. The article deals with the capital punishment in the context of the implementation of such universal values as justice and the right to life. The aim of the survey whose results are presented in the article was to learn the opinions of future resocialization pedagogues, students of the John Paul II Catholic University of Lublin and the Maria Curie-Skłodowska University on the subject of the capital punishment and the justification of its adjudication.
\end{abstract}

Key words: capital punishment; right to life; justice.

System wartości człowieka jest wyznacznikiem jego zachowań, dokonywanych wyborów i stylu życia. Wyznawane wartości wpływają na postawy życiowe, sposób postrzegania i oceniania innych ludzi, zdarzeń, norm i wzorów kulturowych.

Dr hab. TERESA ZuBrZYCKA-MACIĄG - Zakład Teorii Wychowania, Wydział Pedagogiki i Psychologii UMCS; adres do korespondencji: ul. Narutowicza 12, 20-004, Lublin; e-mail: teresa.zubrzycka-maciag@ @oczta.umcs.lublin.pl

JUSTYNA RAK - studentka pedagogiki opiekuńczo-wychowawczej z profilaktyką społeczną; Wydział Pedagogiki i Psychologii UMCS; adres do korespondecnji: e-mail: justynarak16@o2.pl 
Ze względu na rolę wartości w jednostkowym i społecznym życiu człowieka jednym z najważniejszych zadań nauczycieli i wychowawców jest wprowadzanie uczniów w świat wartości uniwersalnych, dzięki którym świat może normalnie funkcjonować, a gatunek ludzki zachowywać swoją egzystencję ${ }^{1}$.

Wartości uniwersalne (ponadczasowe) są silnie zakorzenione w tradycji humanistycznej oraz w doświadczeniu ludzkim, wiążą się ściśle z ontyczną naturą człowieka i decydują o jego osobowym rozwoju. Do wartości tych należy m.in. sprawiedliwość ${ }^{2}$.

Do podstawowych wartości uniwersalnych zaliczane jest również prawo do życia, odnoszące się zarówno do biologicznego istnienia organizmu, jak i jego nienaruszalności. Życie zajmuje centralne miejsce wśród wszelkich dóbr, jakie może posiadać człowiek ${ }^{3}$.

W kontekście powyższego niezwykle skomplikowane i intrygujące staje się zagadnienie kary śmierci, które jednocześnie dotyka wartości sprawiedliwości i prawa do życia „, [...] spraw ostatecznych, a także winy, zadośćuczynienia, w końcu potępienia czy zbawienia [...]”4. Trudne i ważne stają się pytania: Czy osoba, która dopuszcza się czynów skierowanych przeciwko drugiemu człowiekowi, włącznie z zamachem na jego życie, powinna być życia pozbawiona? Czy kara nawet za najcięższe zbrodnie może mieć wymiar utraty życia? Czy odebranie życia groźnemu przestępcy może być usprawiedliwione albo nawet wskazane? Czy i kiedy kara śmierci jest sprawiedliwa? Te i inne pytania postawiono przyszłym pedagogom resocjalizacyjnym, na uczelni katolickiej i świeckiej, przygotowującym się m.in. do pracy ze skazanymi. Wyniki sondażu przedstawiono w niniejszym artykule.

\section{EWOLUCJA KARY ŚMIERCI}

Kara to „fizyczna i/lub psychiczna dolegliwość, która dotyka kogoś, kto naruszył ustalone normy lub reguły wyznaczające określone sposoby postępowania (może to być kara bogów, Boża, kościelna, sądowa, dyscyplinarna, służbowa,

\footnotetext{
${ }^{1}$ M. NowaK, Teorie i koncepcje wychowania, Warszawa 2008; P.T. GoliszeK, Personalistyczny wymiar katechezy, Lublin 2016; T. ZUBRZYCKA-MACIĄG, Wychowanie moralne we wspótczesnej szkole, w: J. GóRNIEWICZ (red.), Edukacja - w stronę kluczowych wartości, Olsztyn-Białystok 2017.

${ }^{2}$ M. ŁовосKI, Wychowanie moralne $w$ zarysie, Lublin 2002.

${ }^{3}$ T. Lewowicki, Aksjologia i cele edukacji, ,Toruńskie Studia Dydaktyczne” 1993, nr 2.

${ }^{4}$ J. Czernicki, Kara (nie)ostateczna „Teologia Polityczna Co Tydzień” 2018, nr 37(129).
} 
administracyjna, pedagogiczna); dolegliwość ta może mieć charakter: nieunikniony (kara naturalna) lub celowy, zamierzony (np. kara kryminalna)",

Biorąc pod uwagę funkcję kary, powszechnie wyodrębnia się trzy grupy teorii tłumaczące cel i istotę karania. Według teorii absolutnych (bezwzględnych) kara wynika z obowiązku odpokutowania przez sprawcę popełnionego przewinienia i jest jego niezbędnym następstwem. Zgodnie z teoriami względnymi (relatywnymi, utylitarnymi) wymierzanie kary przynosi korzyści: naruszonemu porządkowi prawnemu, państwu, ale też przestępcy. W myśl teorii koalicyjnych (mieszanych) kara pełni różne cele w poszczególnych etapach wymierzania sprawiedliwości (np. prewencja generalna, prewencja indywidualna, resocjalizacja $)^{6}$.

Kara śmierci, jako najstarszy rodzaj kary, dawniej stosowana była w następstwie naruszenia obowiązujących norm prawnych. Jej celem było wywołać „cierpienie za popełnione przestępstwo"7 oraz wpływać na stan psychiczny ludności poprzez urealnianie możliwości utraty życia ${ }^{8}$.

Genezę kary śmierci wyjaśniają różne teorie opisujące prawo prymitywne (m.in. teoria zemsty, porachunek osobisty, odwet publiczny $)^{9}$.

Szczegółowe informacje o najstarszych praktykach wykonywania kary śmierci, powodach jej wykonywania oraz różnych, często bardzo drastycznych praktykach pozbawiania skazańców życia (w tym także osób niewinnych) zawarte są w literaturze przedmiotu ${ }^{10}$.

„Stanowisko Kościoła wobec kary śmierci kształtowało się w starożytności w niełatwym do zauważenia napięciu: Kościół w zasadzie tej kary nie potępiał, zarazem jednak nie ukrywał, że wolałby, żeby w ogóle takiej kary nie

5 J. ŚNIECIŃSKI, Encyklopedia pedagogiczna XXI wieku, t. II, Warszawa 2003, s. 529.

6 Tamże.

${ }^{7}$ J. ŚwitKa, Filozoficzne i socjologiczne ujęcie kary, w: M. KuĆ, I. NiEWIAdOMSKA (red.), Kara kryminalna. Analiza psychologiczno-prawna, Lublin 2004.

${ }^{8}$ Zob. A. GRZEŚKOWIAK (red.), Prawo karne w pogladach profesora Juliusza Makarewicza, Lublin 2005; K. BUTOWSKI, Dopuszczalność kary śmierci w ujęciu Tadeusza Ślipki. Kara śmierci rekapitulacja uprawnionej obrony, „Studia Ecologiae et Bioethicae” 2010, nr 8; A. GRZEŚKOWIAK, Znieść kare śmierci!, „Palestra” 1982, nr 9-10.

${ }^{9}$ Zob. J. ŚwITKA, Kara kryminalna na tle osobowości przestępcy, Rzeszów 2013; D. MIELNIK, Kara śmierci w polskim prawie karnym. Refleksje historyczno-dogmatyczne, Łódź 2017.

${ }^{10}$ Zob. m.in. B. BARTUSIAK, Kara śmierci $w$ świetle sporu o racjonalizacje kary, Warszawa 2011; J. WARYLEWSKI, Kara: podstawy filozoficzne i historyczne, Gdańsk 2007; D. MIELNIK, Kara śmierci w polskim prawie karnym; J. BARDACH, Prawo sadowe polskiego średniowiecza, w: J. BARDACH, B. LEŚNOdORSKI, M. PIETRZAK, Historia ustroju i prawa polskiego, Warszawa 2009. 
było" ${ }^{11}$. Ojcowie Kościoła nie zgadzali się na stosowanie kary głównej w obszarze porządku kościelnego, lecz zezwalali na możliwość korzystania $\mathrm{z}$ niej przez władzę publiczną ${ }^{12}$.

\section{KARA ŚMIERCI W POLSKIM PRAWIE KARNYM OD 1932 ROKU DO CZASÓW WSPÓŁCZESNYCH}

Zgodnie z Kodeksem karnym z dnia 11 lipca 1932 r. kara śmierci tworzyła jedną z czterech głównych kar. Orzekano ją opcjonalnie z pozbawieniem wolności za pięć przestępstw, tj.: atak na niepodległy byt państwa, napaść na zdrowie bądź życie Prezydenta Rzeczypospolitej, działalność sabotażową w czasie wojny, typ kwalifikowany zdrady wojennej i wykonywano poprzez powieszenie ${ }^{13}$.

Przemiany przedwojennego prawa karnego realizowano poprzez dołączanie do Kodeksu karnego z 1932 r. serii aktów normatywnych, które powiększały w istotny sposób liczbę srogich sankcji - również kary śmierci. W Kodeksie karnym z 1969 roku kara śmierci znalazła się w osobnym przepisie ${ }^{14}$. Zaplanowano ją za dziewięć przestępstw: spiskowanie przeciwko PRL; akt terrorystyczny; rabunek/rozbój; szpiegostwo; szkodnictwo i sabotaż; zabójstwo; przestępstwo gospodarcze; zdrada ojczyzny, niezrealizowanie lub odmowa realizacji rozkazu bądź jego realizacja niezgodnie z przedmiotem sytuacji bojowej ${ }^{15}$. Do roku 1981 karą śmierci zagrożone były 24 przestępstwa ujęte w różnych ustawach. Owa kara określona była jako sankcja alternatywna, co oznaczało, że w każdej sytuacji na jej miejsce można było zawyrokować karę 25 lat pozbawienia wolności ${ }^{16}$.

W oparciu o Kodeks karny z 1969 r. oraz zarządzenie Ministra Sprawiedliwości z 26 czerwca 1970 r. przeprowadzenie kary głównej miały charaktery-

11 J. SAlij OP, Kościót wobec kary śmierci, „Teologia Polityczna Co Tydzień” 2018, nr 37(129) (dostęp: 2.10.2019).

12 D. MIELNIK, Kara śmierci $w$ polskim prawie karnym.

13 A. GrZeśKowiak, Kara śmierci w polskim prawie karnym, Toruń 1982.

${ }^{14}$ B. BARTUSIAK, Kara śmierci w świetle sporu o racjonalizacje kary, Warszawa 2011, s. 194.

15 D. MiELnIK, Kara śmierci w polskim prawie karnym.

${ }^{16}$ Zob. A. GRZEŚKOWIAK, Kara śmierci w polskim prawie karnym, s. 74-119; M. MITERA, M. ZUBIK, Kara śmierci w świetle doświadczeń wspótczesnych systemów prawnych, Warszawa 1998, s. 101-108. 
zować: pewność, humanitarność, niezwłoczność, niepubliczność oraz szybkość. Pewność określała niezawodność i dokładność. Humanitarność wiązała się z zakazem stosowania nadmiernego bólu oraz krzywdy. Niezwłoczność oznaczała, że kara miała być wykonana wkrótce po uprawomocnieniu się wyroku. Niepubliczność zaś znaczyła, że obecne przy egzekucji mogą być ściśle wskazane osoby, czyli prokurator, lekarz, dyrektor zakładu karnego oraz duchowny w przypadku gdy skazany będzie miał takie życzenie. Natomiast szybkość mówiła o natychmiastowej śmierci osoby skazanej, wykonywanej przez powieszenie, a w przypadku żołnierzy rozstrzelanie ${ }^{17}$.

\section{ZNIESIENIE KARY ŚMIERCI W POLSCE}

Obowiązywanie kary głównej w Polsce trwało do 1988 roku, kiedy to zaczęło się tzn. faktyczne moratorium na jej wykonywanie. Objawiało się ono tym, że Sąd Najwyższy konsekwentnie zmieniał orzekane przez Sądy Wojewódzkie werdykty śmierci na karę 25 lat pozbawienia wolności, bądź stosował prawo łaski. Formalne moratorium wprowadziła Ustawa z 12 lipca 1995 r. Zawieszała ona realizację kary śmierci na pięcioletni okres. Pomimo tego nie uchylono tej kary z katalogu kar ani nie zakazywano jej osądzania ${ }^{18}$.

Kodeks karny, uchwalony 6 czerwca 1997 r., nie zawierał już kary śmierci w katalogu kar zasadniczych. Współcześnie w doktrynie karę tę określa się jako „karę nieznaną ustawie” lub „wielką nieobecna”. W czasie IV kadencji Sejmu Rzeczypospolitej Polskiej (2004 r.) zgłoszono do laski marszałkowskiej projekty poselskie przywrócenia kary śmierci, jako sankcji o charakterze wyjątkowym. Była ona zaplanowana za najcięższe przestępstwa, w tym morderstwo w typie podstawowym i kwalifikacyjnym. Zdaniem wnioskodawców przywrócenie kary śmierci służyłoby zwiększeniu poczucia bezpieczeństwa obywateli i jednocześnie pozwoliłoby zmniejszyć koszty utrzymania skazanych w zakładach karnych. Projekty te nie zostały jednak przyjęte ${ }^{19}$.

Stanowisko Kościoła w sprawie kary śmierci dopuszczało jej stosowanie „pod określonymi warunkami” aż do czasów pontyfikatu obecnego papieża. Zgodnie z zapisem z Katechizmu Kościoła Katolickiego z 1992 roku zatwierdzonego przez Jana Pawła II: „Kiedy tożsamość i odpowiedzialność winowaj-

\footnotetext{
${ }^{17}$ D. MielniK, Kara śmierci w polskim prawie karnym, s. 220-221.

${ }^{18}$ B. BARTUSIAK, Kara śmierci w świetle sporu o racjonalizacje kary.

19 D. MielniK, Kara śmierci w polskim prawie karnym.
} 
cy są w pełni udowodnione, tradycyjne nauczanie Kościoła nie wyklucza zastosowania kary śmierci, jeśli jest ona jedynym dostępnym sposobem skutecznej ochrony ludzkiego życia przed niesprawiedliwym napastnikiem" ${ }^{20}$. Postanowienie to, bardzo ostrożne w zapisie, ,pozostawało w zgodzie z dotychczasowym ujęciem możliwości wykonania kary ostatecznej przekazywanym od Ojców i Doktorów Kościoła przez dwa tysiące lat"21. Aktualnie, decyzją papieża Franciszka, zapis o dozwoleniu stosowania kary śmierci został zniesiony wykluczając ją absolutnie z porządku możliwości, niezależnie od okoliczności ${ }^{22}$.

Dyskusje i spory na temat zasadności stosowania kary śmierci i ujęcia jej w kodeksie karnym trwają i zapewne będą trwały. Jako uzasadnienie potrzeby orzekania kary śmierci wskazuje się m.in. następujące argumenty: a) kara śmierci jest jedyną sprawiedliwą karą w obliczu niektórych zbrodni, dlatego jej eliminacja powoduje naruszenie reguły sprawiedliwości; po wykonaniu kary śmierci można mieć pewność, że kryminalista nie dopuści się kolejnych przestępstw, więc jest to ochrona społeczeństwa przed ciężkimi zbrodniami; kara śmierci jest zgodna z poglądem znaczącej części społeczeństwa, nasyca pragnienie zadośćuczynienia bliskich ofiary za udręki jej i swoje; śmierć mordercy, oceniana w wymiarze religijnym, może być swoista pokuta, a w wymiarze świeckim - zadośćuczynieniem; kara śmierci jest niedroga i nie obarcza społeczeństwa kosztami wieloletniego utrzymania kryminalisty w zakładzie karnym; dobro społeczeństwa należy traktować priorytetowo wobec dobra jednostki; kara dożywotniego pozbawienia wolności zamiast kary śmierci pozwala sprawcy poczuć się bezkarnie i stwarza ryzyko popełnienia kolejnej zbrodni, np. na współwięźniach lub strażnikach; kara śmierci nie jest złem moralnym i może korzystnie wpłynąć na formowanie się kultury prawnej oraz aksjologicznej ludności ${ }^{23}$.

Przeciwnicy kary śmierci podważają jej sens i rację bytu. Twierdzą, że jest ona złem samym w sobie i jest sprzeczna z zasadami moralności. Jako argumenty, popierające swoje stanowisko podają: kara główna przeczy zasadzie humanitaryzmu, można ją określić jako „zabójstwo w majestacie prawa” albo zalegalizowanie odwetu; najwyższą wartością jest życie ludzkie, nikt nie ma prawa zabić człowieka; V Przykazanie Dekalogu brzmi „Nie zabijaj!”, nie

\footnotetext{
${ }^{20}$ Za: J. CZERNIECKI, Kara (nie)ostateczna.

21 Tamże.

22 Tamże.

${ }^{23}$ B. BARTUSIAK, Kara śmierci w świetle sporu o racjonalizacje kary.
} 
powinno przewidywać się wyjątków; kara śmierci odbiera skazanemu prawo do godnego zakończenia życia; kary śmierci nie można odwrócić, co wiąże się z brakiem możliwości na poprawienie ewentualnych pomyłek; społeczeństwo jest tworzone przez jednostki, a więc nie można go traktować jako ważniejsze niż jednostki; jest ona sankcją niepodzielną i nie ma możliwości jej różnicowania, co sprawia, że jest niesprawiedliwa; kara śmierci oddziałuje na społeczeństwo demoralizująco; zastosowanie kary śmierci może doprowadzić do swego rodzaju adoracji kryminalisty jako ofiary; skazanie na śmierć nie jest karą, gdyż obejmuje wewnętrzną sprzeczność: niweczy cel wychowawczo-resocjalizacyjny i nadzieję na zmianęe ${ }^{24}$.

Wydaje się, że nie ma możliwości jednolitego rozwiązania sporu o zasadność orzekania kary śmierci. Oparty jest on bowiem na pozostających ze sobą $\mathrm{w}$ antynomii poglądach na karę w ogóle ${ }^{25}$. W kontekście powyższego interesujące jest poznanie opinii na temat kary śmierci młodych ludzi, studentów pedagogiki resocjalizacyjnej przygotowujących się do pracy z osadzonymi w zakładach karnych.

\section{WYNIKI BADAŃ WŁASNYCH}

Celem badań sondażowych było poznanie opinii studentów uczelni świeckiej (UMCS) i katolickiej (KUL) na temat stosowania kary śmierci. Posługując się ankietą własnej konstrukcji starano się ustalić m.in.: Czy badani studenci czują się bezpiecznie w naszym kraju? Jaką mają wiedzę na temat kary śmierci? Jaki jest ich stosunek do kary śmierci? Jak oceniają sprawców przestępstw? Czy uważają, że mordercy mają prawo do życia?

Badania zrealizowano w 2019 roku w grupie 85 studentów resocjalizacji, przy czym zdecydowaną większość badanych (96\%) stanowiły kobiety. Wśród badanych 40 osób było studentami UMCS, zaś 45 osób to studenci KUL. Większość badanych studentów KUL (66,5\%) miało od 19 do 21 lat, 5\% miało powyżej 24 lat, zaś pozostali studenci tej uczelni to osoby między 22 a 24 rokiem życia. Wśród studentów UMCS badani w wieku 19-21 lat stanowili $52,5 \%$, studentów mających $22-24$ lata było $42,5 \%$ i również $5 \%$ badanych z tej uczelni stanowili studenci mający więcej niż 24 lata. Większość studentów z obydwu uczelni (60\% KUL i 55\% UMCS) to mieszkańcy mniej-

\footnotetext{
24 Tamże; A. Marek, V. Konarska-Wrzosek, Prawo karne, Warszawa 2016.

25 A. GRZEŚKOWIAK, Kara śmierci w polskim prawie karnym.
} 
szych i większych miast. Pozostali zaś (40\% KUL i 45\% UMCS) są mieszkańcami wsi.

W odpowiedzi na pierwsze pytanie ankiety dotyczące bezpieczeństwa w naszym kraju, zdecydowana większość badanych (88,5\% KUL i $75 \%$ UMCS) oceniła, że w Polsce żyje się bezpiecznie. Inaczej jednak sytuacja przedstawia się kiedy badani mieli ujawnić czy obawiają się, że oni sami lub ich bliscy mogą stać się ofiarą przestępstwa. Poczucie zagrożenia ujawniło w tej sytuacji aż $62 \%$ badanych z KUL i 52,5\% studentów UMCS.

Zapytani o to, czy w ciagu ostatnich 3 lat oni sami lub ich bliscy byli ofiarami działalności przestępczej, aż 26,5\% studentów KUL i $30 \%$ badanych z UMCS udzieliło odpowiedzi twierdzącej. W tym kontekście poczucie zagrożenia studentów okazuje się uzasadnione.

Kolejne pytanie służyło zebraniu opinii badanych na temat skuteczności systemu prawnego $\mathrm{w}$ Polsce $\mathrm{w}$ zapobieganiu przestępczości. $\mathrm{Z}$ otrzymanych danych wynika, że badani z KUL lepiej oceniają nasz system prawny, bowiem aż $45 \%$ osób z tej uczelni uznało go za raczej skuteczny w zapobieganiu przestępczości. Do tej opinii przychyliło się tylko $22,5 \%$ badanych z UMCS. Niestety większość studentów (55\% z KUL i 77,5\% z UMCS) miała odmienne zdanie na ten temat.

Zapytani o zasadność stosowania kary śmierci w Polsce, blisko połowa $(47,5 \%)$ studentów UMCS wyraziła przekonanie, że ta kara powinna być stosowana w Polsce, $40 \%$ jest przeciwnego zdania, zaś pozostali nie mieli sprecyzowanej opinii $w$ tym zakresie. Studenci KUL okazali się bardziej humanitarni, bowiem aż $62 \%$ wyraziło swój sprzeciw wobec wprowadzenia kary śmierci w naszym kraju, zaś jej przywrócenie poparło $22 \%$.

W nawiązaniu do poprzedniego pytania poproszono badanych o wyrażenie opinii o celowość stosowania kary śmierci. Zapytano zatem, czy kara śmierci może być efektywnym sposobem zapobiegania przestępstwom. W opinii większości studentów UMCS $(62,5 \%)$ i 36\% studentów KUL kara śmierci spełniałaby taką rolę. Na pytanie zaś czy kara śmierci powinna być wymierzana jako „Zadośćuczynienie sprawiedliwości” 40\% studentów UMCS i 18\% studentów KUL odpowiedziało twierdząco, zaś pozostali badani byli przeciwnego zdania. Ponadto - zdaniem 55,5\% studentów KUL i 47,5\% UMCS - wykonywanie kary śmierci sprzyjałoby szerzeniu się okrucieństwa.

Zapytano też badanych o to, jak oceniają oni przestępców popełniających najcięższe zbrodnie wymierzone przeciwko drugiemu człowiekowi. $\mathrm{Z}$ badań wynika, że w opinii połowy (50\%) studentów UMCS tacy są osobami tak głęboko zdemoralizowanymi, że nie mają żadnych szans na resocjalizację. Taką opinię podzieliło również $31 \%$ badanych z KUL. 
Konsekwentnie do poprzednich odpowiedzi również i w kolejnym pytaniu ujawniła się pewna rozbieżność opinii między studentami uczelni katolickiej i świeckiej. Na pytanie: Czy w Pana(i) opinii kara dożywotniego pozbawienia wolności jest odpowiednim zamiennikiem kary śmierci? twierdząco odpowiedziało 75\% studentów KUL i 55\% studentów UMCS. W odczuciu pozostałych studentów pozbawienie kogoś wolności do końca życia nie spełnia takiej samej roli jak kara śmierci.

Zapytano zatem badanych czy ich zdaniem sprawcy najpoważniejszych przestępstw (np. zabójstwo, gwałty ze szczególnym okrucieństwem) mają prawo do życia? Z odpowiedzi na to pytanie wynika, że zdaniem zdecydowanej większości badanych z KUL $(75,5 \%)$ nawet najgroźniejszym przestępcom nie można odbierać prawa do życia. Pozostali studenci tej uczelni mieli odmienne zdanie w tej sprawie. Odwrotnie sytuacja przedstawia się w odniesieniu do badanych z UMCS. Studenci z uczelni świeckiej w większości (65\%) uważają, że sprawcy najpoważniejszych przestępstw nie powinni mieć prawa do życia.

Poproszeni o opinię w sprawie ewentualnego różnicowania w orzekaniu kary śmierci ze względu na płeć studenci obu uczelni byli zgodni, iż w wymierzaniu kary płeć nie ma znaczenia i wszystkich trzeba traktować sprawiedliwie, co oznacza, że kobieta zasługuje na taką samą karę jak mężczyzna za popełnienie takiej samej zbrodni.

Odpowiadając na pytanie czy zabójstwo można usprawiedliwić jako czyn popełniony w afekcie bądź podyktowany obroną własną bardziej wyrozumiali okazali się studenci UMCS. Wszyscy badani z tej grupy oraz $3 / 4$ studentów KUL wyraziło przekonanie, że popełnienie zabójstwa może być usprawiedliwione, jeśli dokonane zostało pod wpływem silnych emocji, np. w walce o własne życie lub zdrowie. Wśród studentów KUL $11 \%$ nie miało zdania na ten temat, zaś pozostałe uważają, że zabójstwa nie da się niczym usprawiedliwić i nie wolno tego robić.

Zapytani jednak, czy rodzic, który dopuścił się zabójstwa w obronie swojego dziecka, zasługuje na karę śmierci?, wszyscy studenci UMCS oraz $84 \%$ studentów KUL odpowiedziało, że nie. Pozostali studenci KUL nie mieli sprecyzowanego zdania w tej kwestii.

Poproszono też badanych o wskazanie jakie formy wykonania kary śmierci są - według nich - dopuszczalne albo najwłaściwsze. Odpowiadając na to pytanie blisko 60\% (59,5\%) studentów KUL stwierdziło, że jest przeciwnikiem kary śmierci i żadna forma jej wykonania nie jest ich zdaniem odpowiednia. Pozostali badani z tej grupy wskazywali na kilka możliwych form wymierzania kary śmierci: podanie trucizny (16\%), krzesło elektryczne (11\%), 
śmierć w taki sposób, w jaki skazany pozbawił życia innego człowieka $(2,5 \%)$ oraz powieszenie $(2,5 \%)$. Wśród badanych studentów UMCS jedynie $27,5 \%$ podkreśliło, że jest przeciwnikiem stosowania kary śmierci i żadna jej forma nie jest odpowiednia. Pozostali studenci do właściwych form wykonania kary śmierci zaliczyli: śmierć w takiej formie, jaką zadał skazany $(39,5 \%)$, podanie trucizny $(29,5 \%)$, powieszenie $(9,5 \%)$, krzesło elektryczne $(9,5 \%)$.

Zapytani o to, za jakie przestępstwa powinna być w Polsce wymierzana kara śmierci, badani studenci KUL odpowiadali, że za: gwałt (31\%), zabójstwo (29\%), atak terrorystyczny (20\%), molestowanie seksualne (13\%), przemoc wobec dzieci $(9 \%)$ oraz szerzenie pornografii $(7 \%)$. Studenci UMCS uważają, iż kara śmierci powinna być orzekana za: gwałt (67,5\%), zabójstwo (65\%), atak terrorystyczny $(37,5 \%)$, molestowanie seksualne $(35 \%)$, przemoc wobec dzieci $(25 \%)$ oraz szerzenie pornografii $(10 \%)$. Konsekwentnie jednak $62 \%$ studentów KUL i $20 \%$ studentów UMCS podkreśliło, iż według nich niezależnie od popełnionego czynu nikogo nie powinno się skazywać na śmierć.

Ostatnie pytanie miało charakter otwarty i służyło poznaniu opinii badanych na temat: czy i w jaki sposób wprowadzenie do kodeksu karnego i orzekanie kary śmierci może wpływać na system wartości społeczeństwa danego kraju? Wśród uzyskanych od badanych odpowiedzi można wyróżnić dwie przeciwstawne kategorie. Osoby, które wskazywały na korzyści społeczne z tytułu wykonywania kary śmierci, jako argumenty podawały: Kara śmierci spowoduje, że ludzie będa wiedzieli co grozi za cięzkie przestęsstwa i może się opamiętaja; Wykonywanie kary śmierci spowodowałoby, że życie byłoby bardziej cenione; Ludzie mieliby większy respekt wobec prawa i człowieczeństwa; Ludzie czuliby się bezpieczniej wiedzac, że zabójca na pewno nigdy nie wyjdzie z więzienia; Może zmniejszyć się przestępczość, ponieważ ludzie przekonaja się, że przestępcy sa sprawiedliwie karani. Przeciwnicy kary śmierci dostrzegali zaś negatywne następstwa wynikające z powodu odbierania życia innym w świetle prawa dla moralności społeczeństwa: Ludzie stana się bardziej brutalni i przestana cenić wartość życia; Jeśli możliwe będzie odbieranie komuś zycia zgodnie z prawem, to wartości moralne społeczeństwa zostana osłabione; Kara śmierci szerzy zło, sprawia, że ludzie traca swoja moralność; Kara śmierci nie daje człowiekowi szansy na zmiane; Ludzie poczuja, że ktoś może władać ich życiem, a każdy powinien sam decydować o sobie; Ludzie stana się zwierzętami, będa zabijać się wzajemnie; Kara śmierci uczy łatwego załatwiania problemu; Kara może spowodować znieczulice społeczna. Zanik procesu resocjalizacji dla osób, które dopuścity się przestępstwa; Taka kara może zapoczatkować społeczne przyzwolenie na okrucieństwo; Przyzwo- 
lenie na karę śmierci uwłacza godności ludzkiej, a każdy z nas posiada nienaruszalna godność dziecka Bożego.

Argumentów za oraz przeciw karze śmierci jest wiele. Pojawiać się mogą pytania o logiczność podejmowania tego rodzaju pytań i powątpiewanie w możliwość jakiegokolwiek rozsądnego rozwiązania sporów na ten temat. Otrzymane wyniki sondażu mogą nasuwać przypuszczenie, że studenci uczelni katolickiej są większymi przeciwnikami kary śmierci i mają większą wiarę w możliwość przemiany człowieka i w efektywność resocjalizacji. Przeprowadzone badania nie uprawniaja jednak do wysuwania uogólnionych i jednoznacznych wniosków. Badane grupy studentów były bowiem zbyt małe, a ponadto nie dowiedziono (nie zastosowano testów porównawczych), że różnice między porównywanymi grupami są istotne statystycznie. Nie można też na podstawie otrzymanych wyników sondażu wnioskować o wpływie programu kształcenia, charakteru lub klimatu uczelni na system wartości studiujących w nich studentów. Być może tak się dzieje, ale możliwe jest również, że to system wartości młodych ludzi decydował o wyborze uczelni. Mimo ograniczeń wyniki podjętych badań mogą stać się inspiracją dla innych, szeroko zakrojonych badań w zakresie podjętej problematyki. Mogą też skłaniać do osobistych refleksji i podejmowania dyskusji z młodymi ludźmi, również z tymi, którzy będą pracować z osobami skazanymi, nad znaczeniem wartości moralnych, uniwersalnych, ponadczasowych: prawem do życia, godności, sprawiedliwości, prawdy, szacunku.

\section{BIBLIOGRAFIA}

BARDACH J., Prawo sądowe polskiego średniowiecza, w: J. BARDACH, B. LEŚNOdORSKI, B. BARTUSiAK, Kara śmierci w świetle sporu o racjonalizację kary, Warszawa 2011.

BUTOWsKi K., Dopuszczalność kary śmierci w ujęciu Tadeusza Ślipki. Kara śmierci rekapitulacją uprawnionej obrony, „Studia Ecologiae et Bioethicae” 2010, nr 8, s. 77-89.

CzERniecki J., Kara (nie)ostateczna „Teologia Polityczna Co Tydzień” 2018, nr 37(129) (dostęp: 2.10.2019).

GOLISZEK P.T., Personalistyczny wymiar katechezy, Lublin 2016.

GrzeŚKowiak A. (red.), Prawo karne w poglądach profesora Juliusza Makarewicza, Lublin 2005.

GRZEŚKOWIAK A., Kara śmierci w polskim prawie karnym, Toruń 1982.

GrZeŚKowiaK A., Znieść karę śmierci!, „Palestra” 1982, nr 9-10, s. 59-67.

LEWOWICKI T., Aksjologia i cele edukacji „Toruńskie Studia Dydaktyczne” 1993, nr 2, s. 51-59.

Łовоскі M., Wychowanie moralne w zarysie, Kraków 2002.

MareK A., KonarsKa-WrzoseK V., Prawo karne, Warszawa 2016. 
MIELNIK D., Kara śmierci w polskim prawie karnym. Refleksje historyczno-dogmatyczne, Łódź 2017.

Mitera M., ZubiK M., Kara śmierci w świetle doświadczeń współczesnych systemów prawnych, Warszawa 1998.

NowAK M., Teorie i koncepcje wychowania, Warszawa 2008.

SALiJ J., Kościół wobec kary śmierci „Teologia Polityczna Co Tydzień” 2018, nr 37(129) (dostęp: 2.10.2019).

ŚNIECIŃSKI J., Encyklopedia pedagogiczna XXI wieku, t. II, Warszawa 2003.

ŚwITKA J., Filozoficzne i socjologiczne ujęcie kary, w: M. KUĆ, I. NIEWIADOMSKA (red.), Kara kryminalna. Analiza psychologiczno-prawna, Lublin 2004.

ŚwITKA J., Kara kryminalna na tle osobowości przestępcy, Rzeszów 2013.

WARYLEWSKI J., Kara: podstawy filozoficzne i historyczne, Gdańsk 2007.

ZUBRZYCKA-MACIĄG T., Wychowanie moralne we współczesnej szkole, w: J. GóRNIEWICZ (red.), Edukacja - w stronę kluczowych wartości, Olsztyn-Białystok 2017.

\section{KARA ŚMIERCI VERSUS PRAWO DO ŻYCIA W OPINII PRZYSZŁYCH PEDAGOGÓW}

St r e s z c z e n i e

Wyznacznikiem postaw człowieka, jego wyborów i sposobu oceniania zdarzeń jest system wyznawanych wartości. W dobie pluralizmu wartości współczesnego społeczeństwa szczególnego znaczenia nabierają wartości uniwersalne, które warunkują zachowanie ludzkiej egzystencji i trwanie świata. Do podstawowych wartości uniwersalnych należy prawo do życia oraz sprawiedliwość. Artykuł dotyczy kary śmierci, która wyklucza jednoczesne urzeczywistnianie tych wartości. Celem badań sondażowych, których wyniki przedstawiono w artykule, było poznanie opinii przyszłych pedagogów resocjalizacyjnych, studentów KUL i UMCS, na temat kary śmierci i sprawiedliwości jej orzekania.

Słowa kluczowe: kara śmierci; prawo do życia; sprawiedliwość. 